\title{
The reconstruction of the Museum of Warsaw - current architectural interventions in a monument of great significance for the history of conservation in Poland
}

\author{
Jerzy Wowczak \\ pracownia.wowczak@gmail.com | 이 http://orcid.org/0000-0001-6337-6943 \\ Faculty of Architecture and Fine Arts, Andrzej Frycz Modrzewski \\ Krakow University
}

\begin{abstract}
Scientific Editor: Mateusz Gyurkovich, Cracow University of Technology Technical Editor: Matgorzata Sikora, Cracow University of Technology Press Language Editor: Tim Churcher, Big Picture Typesetting: Matgorzata Murat-Drożyńska, Cracow University of Technology Press
\end{abstract}

Received: March 31, 2020

Accepted: September 11, 2020

Copyright: (c) 2020 Wowczak. This is an open access article distributed under the terms of the Creative Commons Attribution License, which permits unrestricted use, distribution, and reproduction in any medium, provided the original author and source are credited.

Data Availability Statement: All relevant data are within the paper and its Supporting Information files.

Competing interests: The authors have declared that no competing interests exist.

Citation: Wowczak, J. (2020).

The reconstruction of the Museum of Warsaw - current architectural interventions in a monument of great significance for the history of conservation in Poland. Technical Transactions, e2020029. https://doi.org/10.37705/ TechTrans/e2020029

\begin{abstract}
The article presents an analysis of the interventions carried out as part of the revitalisation of the complex of tenement houses on Strona Dekerta Starego Miasta na Rynku (Dekert's Side of the Old Town Market Square) in Warsaw. The design works in question took place between 2014 and 2017, resulting in the reconstruction of the Museum of Warsaw and the adaption of its space to the current needs. The article describes the conservation activities undertaken in the tenement houses over the last one hundred years, the main focus being put on the conditions, project process and final outcome of the revitalisation. As highlighted by the author, the most recent interventions in the Museum of Warsaw's tenement houses were completed with awareness of the object's great historic value as an important component of the Old Town inscribed in the UNESCO World Heritage List. They are an example of typically Polish conservation interventions and a specific attitude towards architectural monuments, which were in great part lost by Poland as a result of warfare.
\end{abstract}

Keywords: theory of monument conservation, protection of monuments, museum design 


\section{口::: technical

\section{Introduction}

"It was generally expected, everywhere and of everyone, that while renovating a monument nothing should be added that does not agree with the spirit of the monument...

After some experience a principle was established that nothing should be added to a monument that agrees with the spirit of the monument..." (Sas-Zubrzycki, 1922: 40).

On $10^{\text {th }}$ and $11^{\text {th }}$ December 2018, the Historical Monuments and Art Conservators Association in Poland organised, as part of the initiatives commemorating the centenary of Poland's conservationist movement, the conference entitled "Preserving the Heritage of the Polish Cultural Space for the Future". The Association boasts to be one of the social organisations continuing the mission of the Society for the Protection of the Monuments of the Past (Polish: TOnZP) established in 1906 in Warsaw (Dettloff, 2010). One of the first architectural activities carried out by the TOnZP in the 1920s was the conversion of the Baryczek tenement house on the Old Town Market Square in Warsaw into its headquarters. The history of the house's conservation over the last one hundred years was presented during the conference, with a paper having been published in the post-conference publication (Wowczak, 2019). The present article constitutes a significantly broadened, academic extension of that text.

The last reconstruction of the building complex forming the Museum of Warsaw's frontage on the Strona Dekerta Starego Miasta na Rynku (Dekert's Side of the Old Town Market Square) took place from 2016 to 2018 (Fig. 1). These eleven tenement houses located in the very heart of the capital's Old Town are an example of typically Polish conservation interventions marked by the experience of losing monument substance as a result of warfare. Additionally, associated with this location are ideas of conservation that, despite being widely accepted in the era of the monument's creation, have been a subject of dispute among experts in the field over the last few decades.

To ease the reader into the topic, let us briefly recount what the debate was all about. The dispute concerning the conservation doctrine had several stages. The development of the conservationist thought lies within the scope of the academic work of Jerzy Frycz (Frycz, 1975), Marian Arszyński (Arszyński, 2007), Pawet Dettloff (Dettloff, 2010), and others. Even the stylistic compromise suggested by Tomasz Pryliński during his restoration of the Cloth Hall (1875-79) could be reduced to the question of whether it is correct to undertake a purist restoration of a building in the spirit of the era that it dates back to.

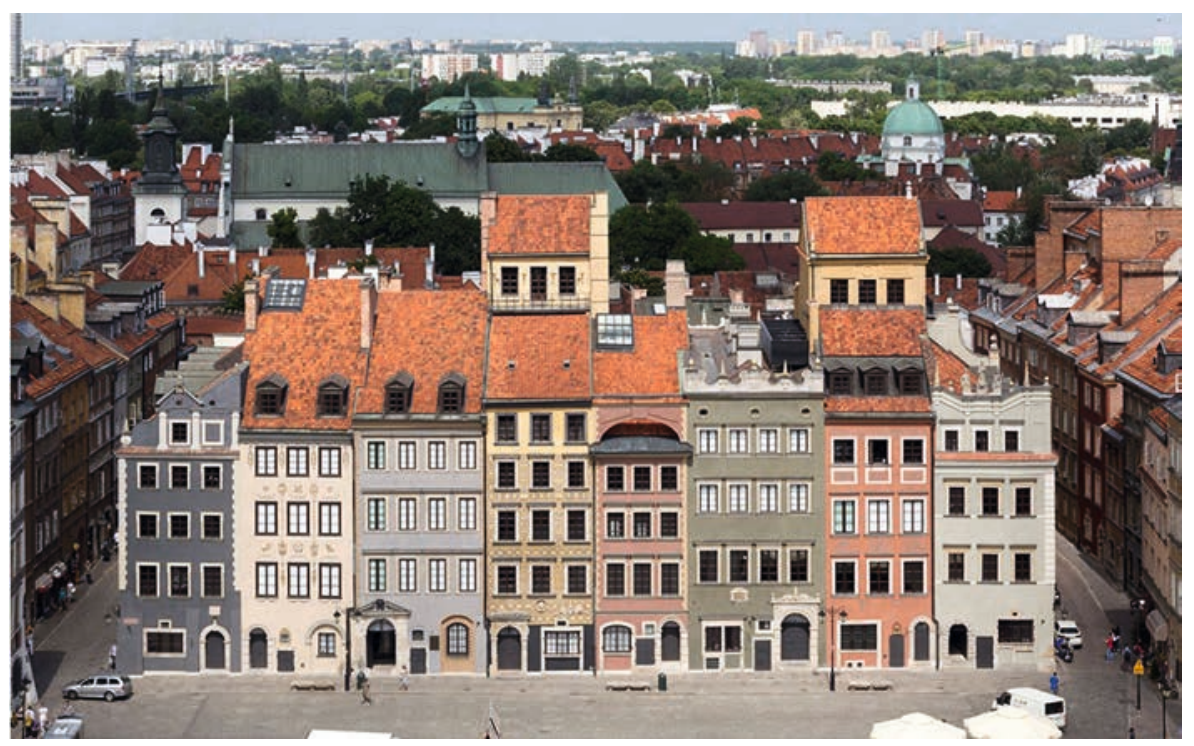

Fig. 1. The Old Town Market Square in Warsaw, tenement houses on the Dekert's Side, the seat of the Museum of Warsaw (photo by Marcin Czechowicz, 2018, property of the Museum of Warsaw) 
Fig. 2. A city map illustrating the extent of the 1850 fire, published in Geneva by the Committee raising funds for helping the fire victims (source: Czaja, 2007)
The then press saw a dispute between the supporters of Viollet-le-Duc's school (Józef Łepkowski, Władystaw Łuszczkiewicz) and the followers of the rule of maintaining the status quo, this is to say maintaining the stylistic versatility and not allowing the accumulated layers to vanish (Pawet Popiel) (Frycz, 1973: 180; 1975: 136; Beiersdorf 1998: 71-93). Nowadays, we tend to forget that a tragic event determined the beginning of this dispute and, in general, the whole of Polish conservationist thought, namely, the 1850 Great Fire of Kraków and the necessity to reconstruct the monuments destroyed by the ravishing flames (Fig. 2). The discussion between Kraków's conservators took place just at the time when John Ruskin formulated his objection to any human intervention into the "divine" imperative of transiency. It needs to be remembered that The Seven Lamps of Architecture was first published in 1849 (Ruskin, 1849), while its first Polish summary was printed in 1902 (Sas-Zubrzycki, 1902). A debate on whether it is appropriate to restore a monument in the spirit of the epoch in which it was built reached its climax when the need arose to revitalise Wawel Castle. It is then that the Polish conservators entered into a conflict with Max Dvorák, the Chair of the Central Committee for the Research and Maintenance of Artistic and Historical Monuments (Krawczyk, 2012).

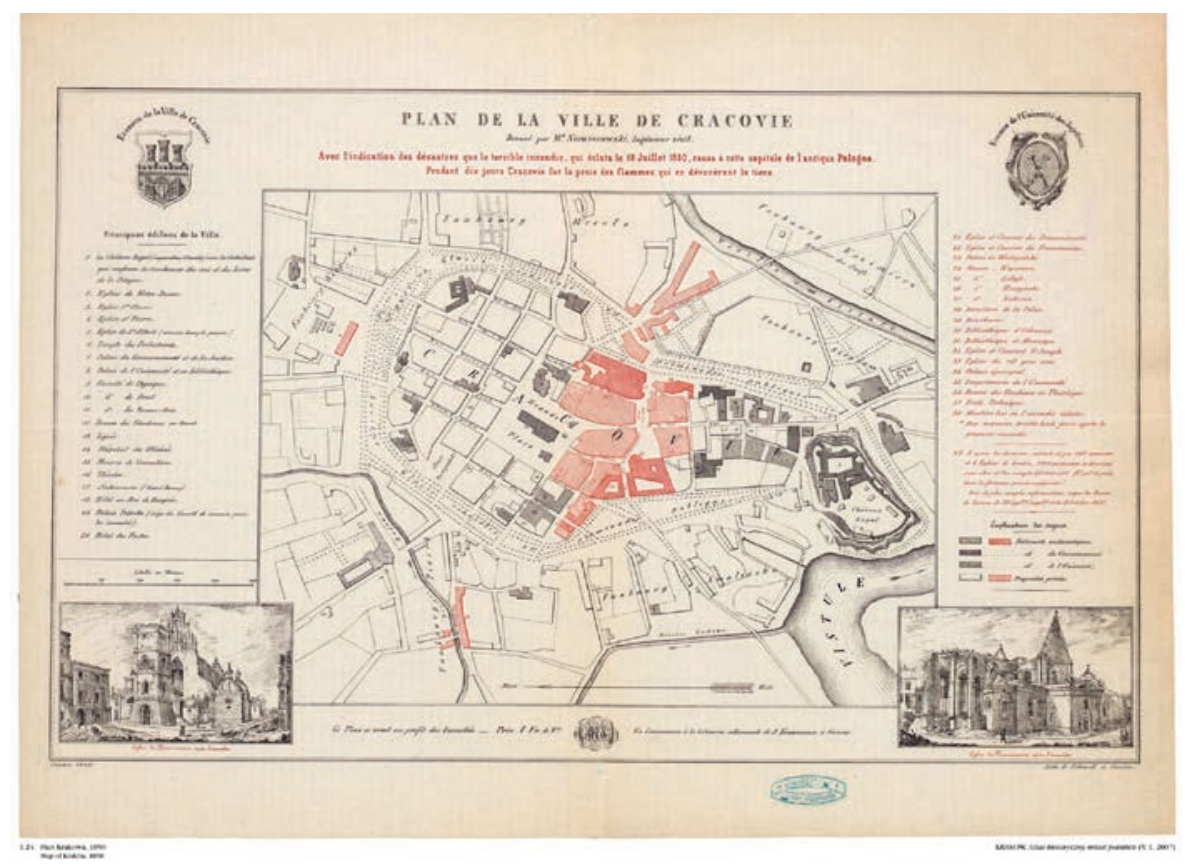

Among Kraków's architects of the time, Józef Muczkowski (Muczowski, 1904) and Klemens Bąkowski (Bąkowski, 1905) took opposing stances. The polemic period seemed to have come to an end with the theses and conclusions of the I Convention of Enthusiasts of Native Monuments in Kraków (1911), during which, any adaptation treatment of a building that "standardised" its appearance and, consequently, falsified the artwork, was condemned as inappropriate (Krzyżanowski, 1912). Those disagreeing with the idea of restoration in line with "the spirit of the epoch" had to give up their principled positions after World War I. In 1920, the Ministry of Art and Culture published the brochure Protection of Monuments and their Conservation. The term "restitution" appears there as synonymous with conservation (Dettloff, 2010: 108). During the II Republic, rebuilding in the spirit of the epoch was sanctioned by role models in the field and in the face of the ravages of war, it was even accepted in the Charter of Athens: "In the case when restoration is inevitable as a result of degradation or destruction, the conference recommends respecting the historic and artistic work of the past not excluding a style of any epoch" (Szmygin, 2015). After World War II, the disagreements lost their importance in light of the need to rebuild the country. 
The ideas behind the reconstruction of the capital's monuments carried out, under the socialist regime, by Professor Jan Zachwatowicz and included reconstruction in the spirit of the heyday of a monument, respect for relics and the anticipation of space needed for modern art. One can have an impression that the wheel of history made a full turn and, when faced with the ravages of war, the $20^{\text {th }}$-century conservators assumed an approach similar to that adopted by Teofil Żebrawski and Karol Kremer while rebuilding burnt Kraków in 1850.

\section{The first conservation of tenement houses undertaken by the Association for the Protection of the Monuments of the Past}

Conservation of the tenement houses on the Dekert's Side has been thoroughly researched and described in two books: Thirteen Old Town Tenement Houses by Stanistaw Żaryn (Żaryn, 1972) and From a Tenement House to a Museum by Matgorzata Popiołek (Popiołek, 2016). Here we will limit ourselves to highlighting the scale of these interventions, referring anyone interested to the aforementioned publications.

We should not neglect the fact that the complex has been an object of conservation works since the beginning of the $20^{\text {th }}$ century. The Old Town in Warsaw, depreciated after 100 years of occupation to the role of an inferior quarter of one of the many cities in a great empire, was nothing more than picturesque, despite its historical value. A chance for the renewal of the Old Town lied in transforming its residential function into a more formal one. Such a pioneering undertaking, forming part of the Old Town's recovery programme, was the public initiative of the Warsaw Association for the Protection of the Monuments of the Past to purchase the Baryczka tenement house at 32 Old Town Market Square. The building was bought in September 1911 and adapted for the TOnZP's needs. The works lasted until 1922 (Popiołek, 2016: 30-50). The restoration involved documenting the monument's historic substance, replacing and reinforcing the structural elements as well as redesigning the spatial layout. Researchers emphasise the importance of that revitalisation for the concept of the regeneration of the Old Town district and the development of Polish museology (Manikowska, 2010; Dzierwa, 2010). How the intervention was perceived by the conservators' community and what the atmosphere was like at the TOnZP's seat is evidenced in its 1930 annual report: "However, given the fact that the idea of restoring monuments appeared and developed in the Baryczka tenement house at the Old Town Square, a close and harmonious symbiosis was established in the first years of Poland's independence between the Conservation Department and the conservation offices. Mutuality of passions, interests and goals caused that all issues, regardless of their importance, were discussed by conservators as part of "the Baryczka case." The experts also took into account the presentations given by representatives of the Conservation Department to the authorities" (Lalewicz, Lisiecki, 1932-1933: 46) (Fig. 3).

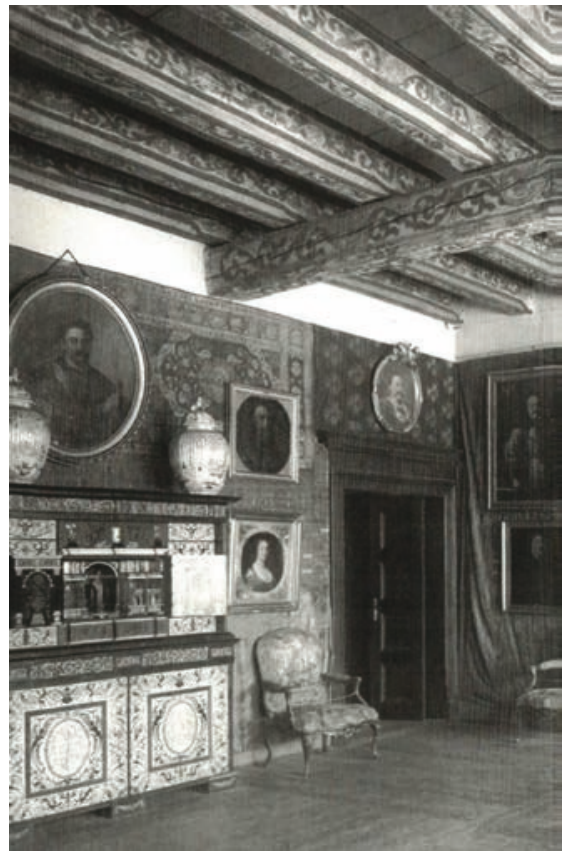

Fig. 3. A photograph from an exhibition organised in the Baryczka tenement house by the Zdobnictwo Polskie, February 1925 (source: NAC reference no: 1-K-6209-1) 


\section{Tenement houses on the Dekert's Side - restoration in the inter-war era}

In 1928, on the tenth anniversary of Poland regaining independence, the polychromes on the tenement houses' elevations were developed by Zofia Stryjeńska and others (Popiotek, 2016: 54-55). The conservators assembly's choice to assign the task of decorating a frontage on the Old Town Market Square to the artist who contributed to the success of the Polish Pavilion at the 1925 Paris Exhibition was a clear sign of the ennoblement of the Polish art déco. In 1933, a solemn session took place in the Baryczka tenement house to mark the twentieth anniversary of the existence of the Association for the Protection of the Monuments of the Past. During the event, Jarostaw Wojciechowski gave an account of the restoration works carried out by that time at the location of the Association's seat (Wojciechowski, 1934). A side effect, yet significant from the point of view of the future fate of the complex, was the architectonic inventory compiled by the students of Warsaw University of Technology at the Unit of Polish Architecture under the supervision of Oskar Sosnowski (Żaryn, 1972: 69-72; Krogulec, 2007; Królikowski, 2004). In 1938, the City Council bought the Baryczka tenement house from the TOnZP and, together with two adjacent tenement houses purchased at the same time, converted them into the Museum of Old Warsaw. The intervention was performed under the eye of Jan Zachwatowicz. In 1938, Stanistaw Hempel carried out a technically demanding and pioneering reinforcement of the intermediate floors of the Kleinpold (Szlichting) and "Pod Murzynkiem" tenement houses. The construction challenge lied in preserving the authentic beams and ceilings covered with valuable painting decorations. The polychromes, dating back to the $17^{\text {th }}$ century, were uncovered and subject to maintenance. The reinforcing and protective actions completed by Professor Hempel in the 1930s in the tenement houses on the Old Town Market Square are considered an important achievement in the field of Polish monument conservation. The construction and conservation works also continued during the Nazi occupation (Żaryn, 1972: 91; Sottan, 2007).

\section{Reconstruction during the rebuilding of the capital}

The second conservation undertaken as part of the Great Rebuilding of the Old Town was also spectacular, although one could have thought that it would pass unnoticed amidst the large-scale reconstruction of the country from the ravages of war. The fortunate fact that the polychromes, protected by the reinforced concrete intermediate floors designed by Professor Hempel, were saved among the ruins of Warsaw increased the importance of the preserved part of the complex. Given their location just on the Old Town Market Square, the buildings, published in thousands of photographs, started to be perceived by the public as symbols of both the destruction and rebuilding of the capital. We believe that they still serve this role, even though 70 years have passed. Special merit should be given here to Professor Jan Zachwatowicz who was widely respected by decision-makers among the architects of post-war Poland and determined the Old Town's reconstruction (Zachwatowicz, 1965). The reconstruction of the housing block on the northern side of the Old Town was led by Stanistaw Żaryn. The works were based on a preserved collection of pre-war inventory sketches and the architect's own research (Krogulec, 2007). Regarding the Dekert's Side, the decision was made to rebuild it with slight alterations in the interior arrangement of the tenement houses. Both the project and its realisation were marked by a conflict between museologists, who were seeking open exhibition space, and conservators, whose objective was to safeguard the historic value of the buildings so well documented before the war. Achieving spacious interior areas was inhibited by the existence of demising walls, different storey heights and circulation paths. A compromise was reached, as a result of which, only 
houses at 28, 38 and 42 Market Square were deprived of stairwells (Żaryn, 1972: 97). Authentic pieces of relic value were preserved and displayed. They included: fragments of walls with vaults, basement floors, stone portals, the attic crowning of the front elevation of the Baryczka tenement house, stone elements of the interior stairs, some details of the original masonry and moulding, linings of sheet metal, door fittings and grates (Wojciechowski, 1953a; Sulimierska, 1953; Grzelachowski, 2010). Most importantly, three ceilings with polychrome decorations were saved on the first and second floors of the tenement house at 34 Market Square. In the years 1949-1954, conservation of the ceilings was performed and the decision made to unveil the oldest paint layers of the ceiling of the first-floor room at the back of the rear track, which remained untreated during the post-war restoration works (Dąbrowski, Żaryn, 1955). During the renovation, a Gothic niche was discovered and displayed in the vestibule of the tenement house at 40 Market Square. The wooden ceiling on beams embedded in the preserved sockets was also reconstructed, causing functional disturbances on the first floor where the floor was raised in part of the front track. Discovering Gothic relics encouraged the conservators to place a mural painting featuring in the museum interior Madonna and the Child moved from the nearby Godswiller (Swignowska) tenement house at 17 Market Square (Fig. 4).

The preserved polychrome was transferred from a piece of wall to then be clarified with the use of conservative methods (Żaryn, 1953b; Koczorowska, Kozarzewski, Kutakowska, Zalewska, 2019). Żaryn's team decided that the new fragments of the object, which previously did not exist in such forms, including stairs, windows, portals, grates etc., be treated "in the spirit of the epoch", in line with the principle established in the previous century. The Gothic (in the cellars and some vestibules), Renaissance (attics, lintel details and doors) and Baroque elements were indicated as being appropriate for such treatment. The eclectic manner of design resonated with the scale of the place and the romantic character of its picturesqueness. This is how the tenement houses were enriched with prime craft details. From the point of view of purist doctrinaires, these elements could be regarded as forgeries. For us, they are proof of the mastery of the then designers and craftsmen in how they dealt with materials' properties. The biggest project challenge predominantly concerned the parts of the architectural decor that were not directly based on historical patterns. In these cases, traditional techniques already used within the object were applied, adding modern expression. Craftsmen and artists worked in agreement with the changes in art characteristic of the epoch, thus bringing an additional value to the complex. Socialist realist details can be observed here, namely forged or welded grates, balustrades, lamps and door fittings inspired both by historic (mainly Baroque) details and folk art (Fig. 5).
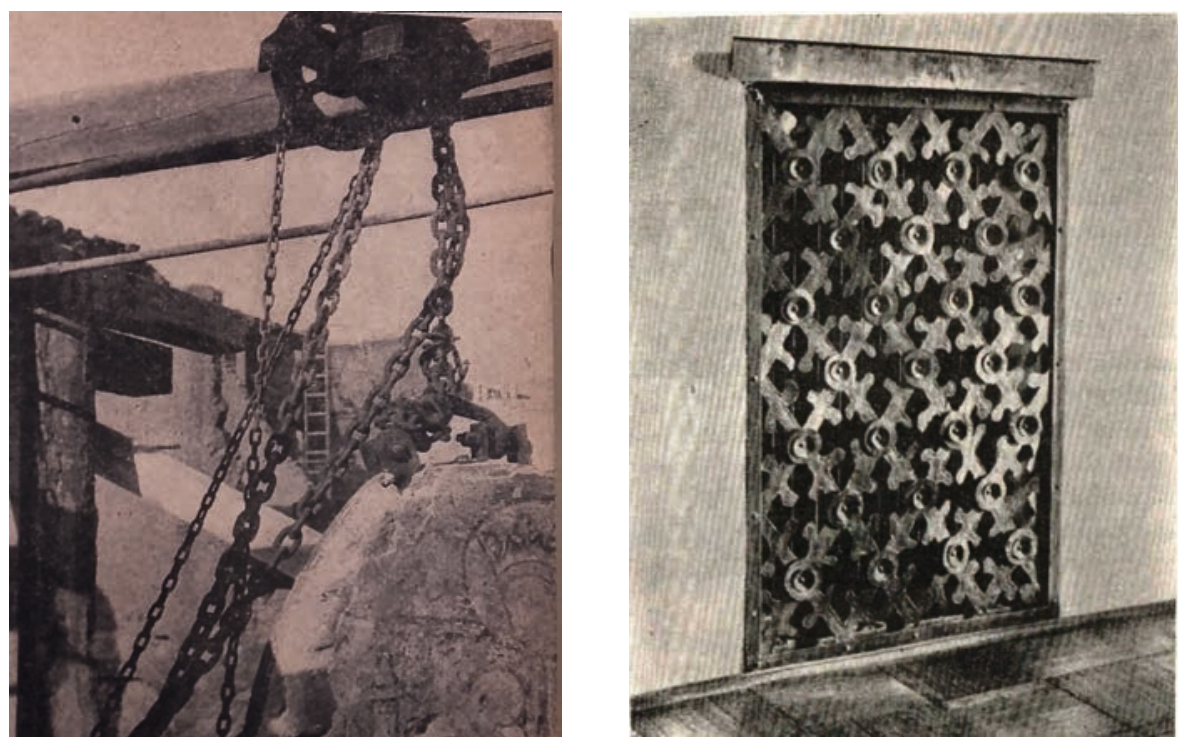

Fig. 4. Transfer of the Gothic polychrome from the tenement house at 17 Market Square in Warsaw (source: Żaryn, 1953b: 171)

Fig. 5. An architectural detail from the 1950s (source: Żaryn, 1972: 141) 
Over the years, the museum acquired excellent new patterns from the post-socialist realism era including showcases and specially designed lamps in some exhibition halls, as well as in the reading room. The exhibitions designed by Stanistaw Zamecznik were of the highest value (Ciesielska, 2007). The preserved photographs prove the masterly moderation and quality of the arrangements of the 1960s. The painting decorations on the front elevations of the tenement houses made in 1953 constituted a topic on its own. The idea to reconstruct the pre-war polychromes was abandoned, although the frescos by Zofia Stryjeńska on the walls of the Kleinpold tenement house were preserved in a pretty good state (Urbanowicz, 1953). Elevations were ornamented with attractive graphic forms corresponding with the spirit of the socialist realism era and sporadically referring to the artistic activities undertaken in 1928. Critics hailed the rebuilt form of the Old Town's tenement houses as a coherent piece of art: "The old and the new have been combined on Warsaw's Market Square. History lent a hand to contemporaneity. The revived part of the old Warsaw makes it possible for us to observe the preserved pieces of historic architecture and monumental art, indicating its current and future development potential. [...] The general colour expression of the Market Square is that of an intentionally subdued whole characterised by subtle, and sometimes even reserved colour scheme." (Wojciechowski, 1953a: 4) In 1953, the polychromes of the Warsaw Old Town on Dtuga Street were indicated as an example of the excellent cooperation between architects and plastic artists within the urban context as part of the development of the socialist realism space (Wojciechowski, 1953b).

\section{Restoration from the years 2011-2018}

The museum played its educational role for 50 years. Then the building's infrastructure became worn out and the place no longer met society's expectations of a museum institution. Nowadays, it is expected that museums, apart from serving educational, scientific and conservation purposes, also play a social and economic role. The primary goal of such institutions is to reach out with their mission to the broadest possible spectrum of social groups and eliminate any forms of exclusion. This is why so much attention is given to the museums' publishing initiatives and library rooms, as well as making the buildings accessible to the disabled. Museums are also the most valuable objects of architectural art and significant landmarks in the urban structures of cities. By organising temporary exhibitions and cultural events, they attract tourists and strongly contribute to the development of cities (Van Aalst, Boogararts, 2003). In the world's biggest metropolises, museum units are combined into complexes, creating prestigious districts. (Hamnett, Shoval, 2008) Smaller museums often serve as places where local communities can integrate and define their identity. The aim of creating both a representative museum worthy of a capital city and an integration place for Warsaw's residents was taken into account by particular exhibition curators and designers of the museum's restoration. The museum's status changed significantly in the 1980s, especially when, in 1980, it was inscribed in the UNESCO World Heritage List, which hoisted the conservation activities from the 1950 s to the rank of a truly valuable intervention. The addition of several elements as part of that reconstruction resulted in the inscription that was against the doctrine formulated in the Charter of Venice. According to Article 12 of this document: "Replacements of missing parts must integrate harmoniously with the whole, but at the same time must be distinguishable from the original so that restoration does not falsify the artistic or historic evidence". The rebuilding of the Old Town barely meets the authenticity criterion, and yet it was appreciated by some of the world's most acclaimed experts in the field of monument conservation (Zachwatowicz, 1981). Given this, Stanistaw Żaryn's treatment had to be acknowledged as a value consistent with the preserved authentic fragments. 


\section{::: technical EDtransactions}

No. $2020 / 029$

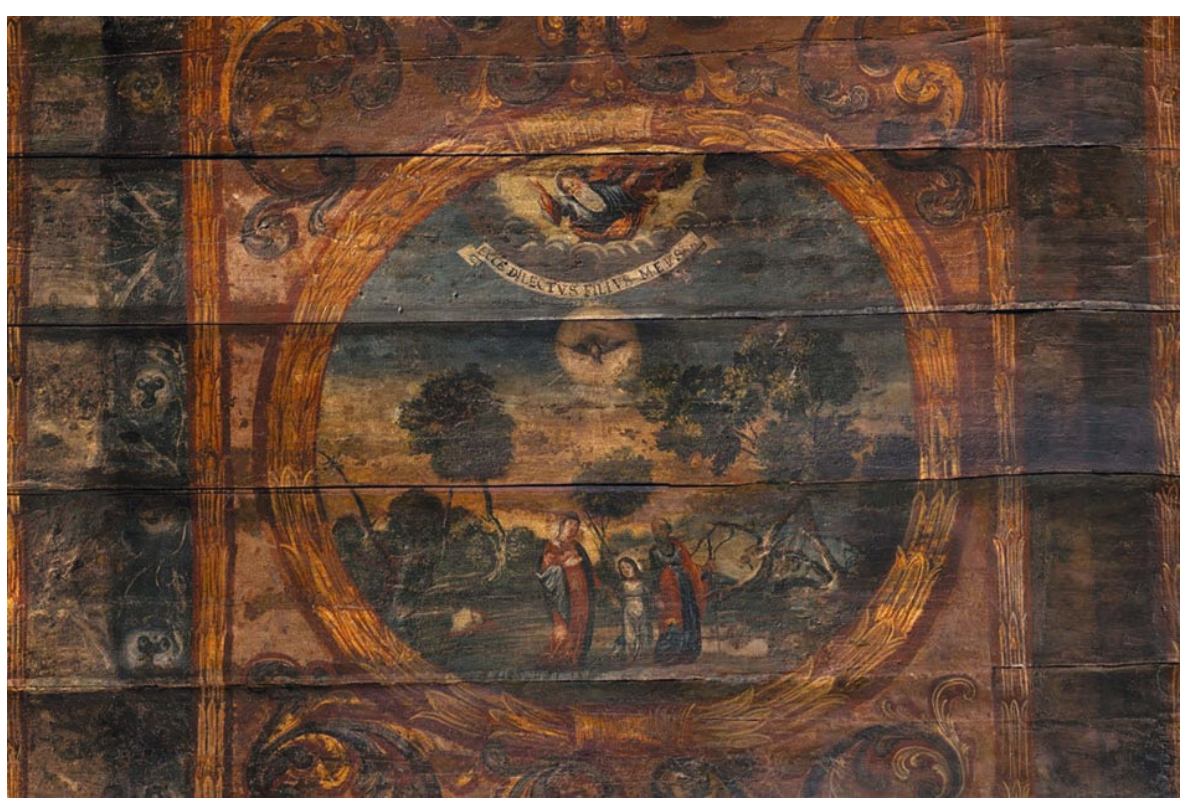

The first conservation works in the cellars were performed in the years 2011-2014. In 2014, the designing team was formed as part of the leading unit, namely the renowned construction office directed by Stanistaw Karczmarczyk $\mathrm{PhD}$ and Wiestaw Bereza PhD. Before joining the project, the team already had the programmes of conservation and restoration works developed by Janusz Mroz and Kamila Wojtowicz, as well as the programme of conservation works "Three polychrome ceilings in the Kleinpold tenement house..." - prepared by Agnieszka Zalewska's team (Fig. 6). In 2013, an important discovery was made. In one of the rooms destined for exhibition, a forgotten wall painting from the times of socialist realism was found that was probably covered in the following era. It is a fresco entitled Forging Scythes created by Wojciech Fangor (Bochiński, 2013). Given the piece's value and the artist's rank, the decision was made to unveil the work (Fig. 7).

The team recognised the design problems involved and submitted a consistent vision to the investor for evaluation. The designers knew that they were dealing with several accumulated layers. The most valuable relic layer, which fortunately survived the ravages of war, included authentic wall pieces, the original masonry and the polychrome ceilings in the vestibule of the tenement house at 40 Market

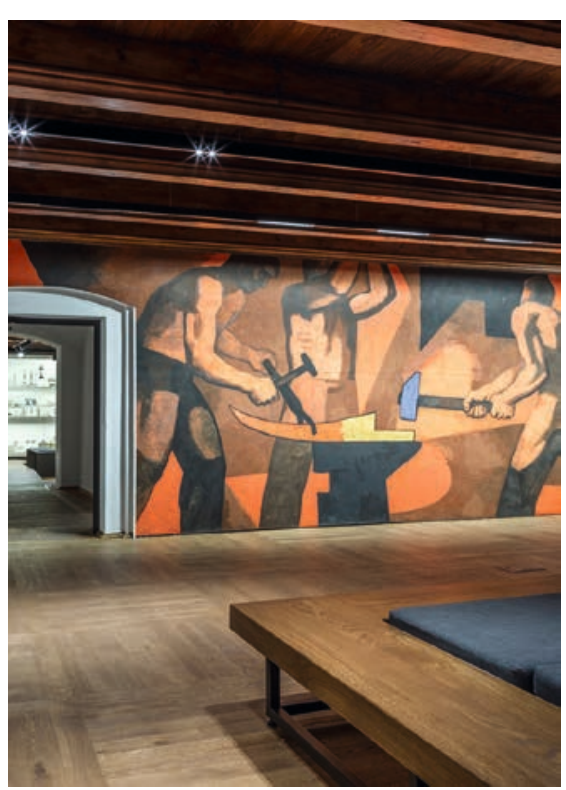
Square. The tenement houses also feature a conservation layer (example of a conservation technique) that is unnoticable for laymen, yet

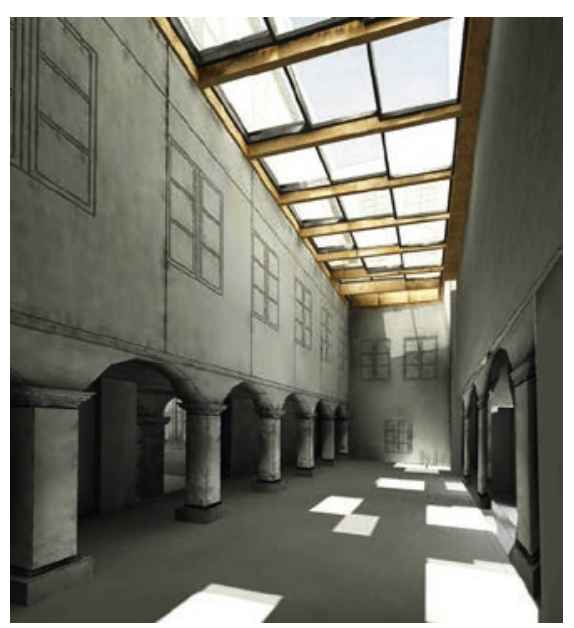

Fig. 6. The original polychrome ceiling in the Kleinpold tenement house (source: Zalewska, 2013)
Fig. 7. The Museum of Warsaw, Forging scythes fresco by Wojciech Fangor (photo by Marcin Czechowicz, 2018, property of the Museum of Warsaw)

Fig. 8. A visualisation of the courtyards' roofing, 2016 (project by author) 
widely recognised and mentioned in professional textbooks. It is made up of the ceilings' structural reinforcements designed by Professor Hempel and the construction style of the inner yards. Importantly, there were also well-preserved conservation art elements from the 1950s that are of great artistic and historic value. The designers conducted a valorisation which proved that all the layers ought to be protected and so, a new problem emerged - how to introduce new elements expected by the user? These were considered in several thematic groups according to the degree of problem complexity. The challenges included: roofing and roofs, ramps for the disabled, toilets, offices, new steps and railings, new interior walls and movable elements; moreover, there was a requirement for interior installations, mainly air conditioning and low-current installations, determining the functioning and safety of both users and collections. It was assumed that technical installations should be maximally concealed in the belief that highlighting technological solutions adopted in the museum's buildings would result in disharmony and disintegration of the previous conservation treatments constituting, in the designers' view, an artwork.

An additional question was also posed: What was the key to the success of Stanistaw Żaryn's restoration? It was proven that it lied in the way the team's predecessors dealt with the material, adopting what could be called "the empowerment of material." In the 1950s, the objects - be they forged, welded, cut or milled, metal or stone - were all given a suitably rich form since they were all meant to be subtly decorative. The team also realised that in the years following the socialist realism era, they were offensive in featuring a certain degree of anachronism and were certainly not fashionable. Yet the passage of time allowed for discovering their unquestionable aesthetic value. None of the used materials were on their own, separate; stonework corresponded with steel elements, and steel with wood. A railing followed the shape of a hand, etc. This dialogue of materials with one another and with the user resulted in focusing attention and the slowing down of perception, encouraging reflection. Resigning from obviousness and applying a manner of designing so distant from the modernist motto "less means more" contributed to the final effect of uniqueness. The challenge was accepted of fitting in to the logic of past events. The roofing of the yards was presented so convincingly that the investor approved it after due consideration (Fig. 8). The dialogue between steel and wood in elements of

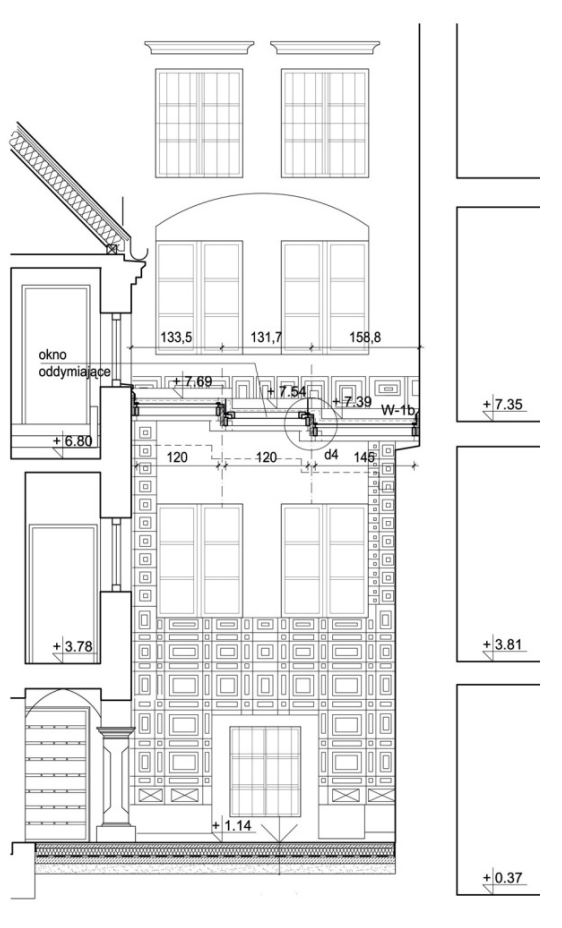
supports, as well as the unusual and unobvious construction layout not corresponding with the load-bearing system, but following the module and proportion, were understood and, eventually, accepted. Only the designers know how much effort it took to fit those rhythmic, ordered planes into the geometry of the walls, roofs and cornices developed by Żaryn's team in line with the romantic, painting-like manner of the picturesque views. Apart from construction problems, challenges were also faced related to the fire insulation of glazed surfaces and the treatment of rainwater. The designers resisted the temptation of applying glass-free glazing (which would facilitate certain architectural solutions) and worked consistently, following the rule of a maximum of a $5 \%$ slope for glass surfaces Fig. 9. A roofing detail, 2016 (project by author) 
accessible solutions, roof tightness was ensured. The designers' team focused on the aspects concerning fire safety solutions. Separation zones were designed with no harm being done to the interior layout and so, for example, a copy of wooden doors was made corresponding to the appropriate fire class. Elements of glazing, skylights and the new separation zone's walls were standardised with the use of steel profile systems. Ventilation of the stairwell of the tenement house at 28 Market Square is guaranteed by an under-floor bifurcated ventilation duct running in the groin of the cellar cradle. The ventilator was hidden below the unloading ramp of the courtyard.

Smoke extraction from the historic stairwell of the Baryczka tenement house was made possible by the stepped formation of the skylight, imitating the former architectural form. The smoke window installed in the actual skylight became invisible when looked at from the stairwell. A gas fire-extinguishing installation in the rooms with polychrome ceilings came as a big challenge. It consisted of the highly discrete conducting of conduits for fire-fighting substance, separating and concealing a proper zone for gas bottles and fixing fire detectors with consideration for the historic ceilings, all of which had to be taken care of by the designers and the contractor. Of extreme difficulty was the development of the ventilation installation. Mechanical ventilation of all utility rooms needed to be ensured, which resulted in a high number of autonomous systems with ventilation control units (Fig. 10). The latter had to be hidden in tight attics with the roof geometry remaining unaltered. Challenges resulting from the construction burden were accompanied by problems concerning the construction of large-size channels and waterproofing, as well as thermal and acoustic insulation. In line with the project assumption to conceal all ventilation ducts in the walls and ceilings, a complex distribution plan was designed taking into account the different widths of the walls on respective floors. The amount of ventilation systems and the lack of possibility to install ducts beneath ceilings or pilasters in the exposition interiors, forced the team to significantly perforate

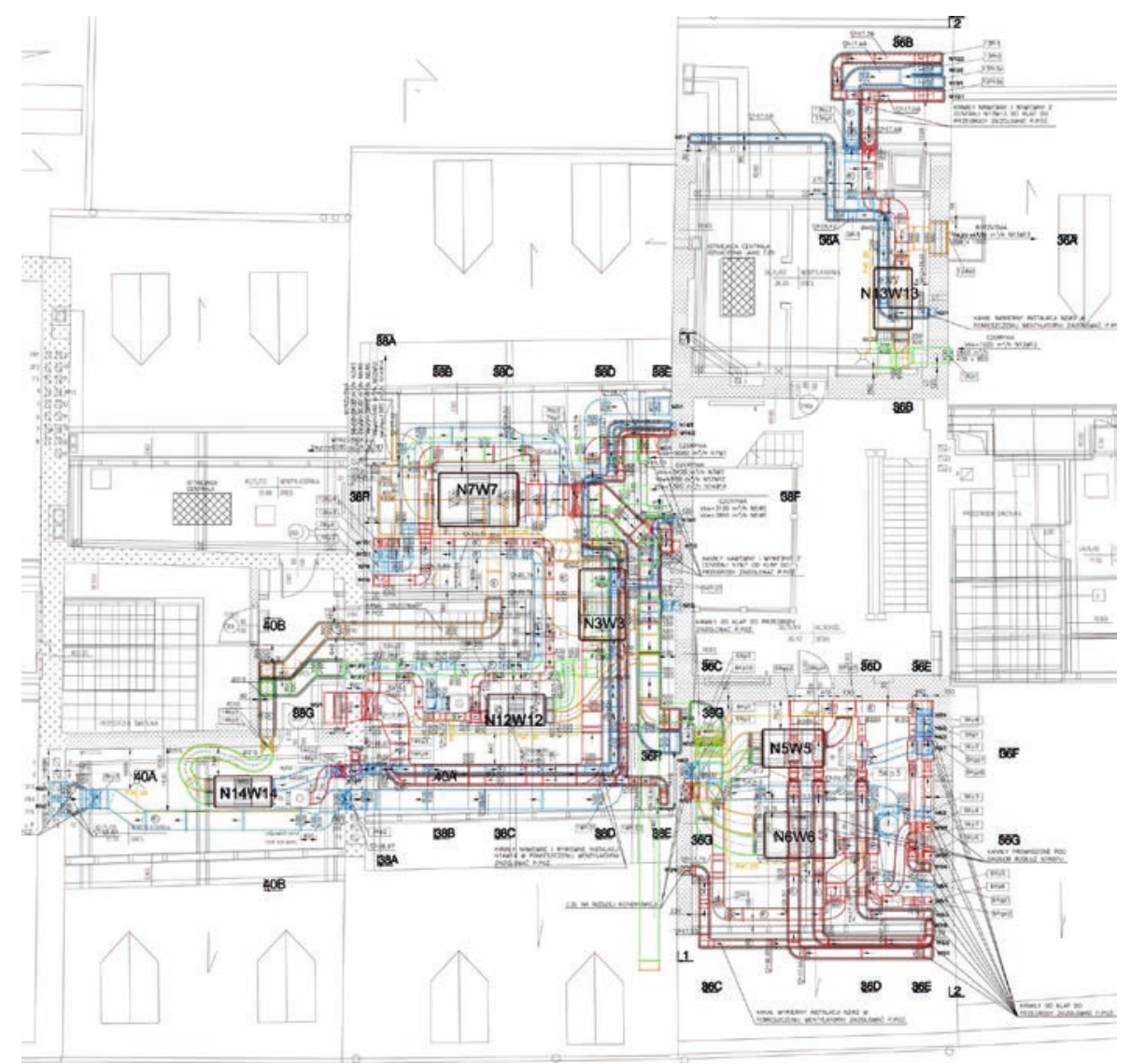

Fig. 10. A drawing of ventilation installation for the Museum of Warsaw, 2016 (project by P. Budzyński and J. Wowczak) 
the walls on all floors. Making deep creases for ducts bore the risk of weakening the bearing walls. This was prevented by applying steel grates made of angle irons anchored to brick walls. Additionally, in sensitive places, next to horizontal openings, carbon fibre tapes were used.

It was not easy to find space for a big cold water unit which was finally located above the only butterfly roof and hidden behind the attic wall of the tenement house at 32 Market Square in such a way that it is not visible from the ground level. A visibility line was drawn, purely for clarity, leading from the furthest point of the Market Square's interior. The aim of fitting into the landscape was among the reasons for the partial replacement of the roof coating and for leaving the patina-covered tiles. The idea was to mix the old roof tiles with new tiles and, consequently, to blend the renovated roofs into the Old Town landscape. A separate designing issue, which starting from the conceptual phase was of special importance to both the investor and the designer, was ensuring that the largest possible number of rooms were accessible for the disabled. A special path was designed to that end based on a system of ramps, mechanical lifts and elevators, slightly changing the floor level in a few places. The designing process did not end after the handing in of the documentation. Changes were already introduced as part of the project architect's supervision during the construction work conducted by the Castellum company from Wroctaw under the direction of Marcin Kozarzewski. Several Conservation Committees were held to take decisions concerning the flashing of elevation details, the elevation's colour scheme, the internal walls and the interior décor. Additionally, painting and moulding elements were meticulously reconstructed, Gothic fragments of the walls were renovated, the portals' missing elements were added, the wooden staircase was maintained, the artistically lavish parquets were regenerated and the electric cables were hidden in Gothic walls' grouts. Above all, the rooms featuring authentic polychromes were protected and separated. Installation works, including those concerning the gas fire-extinguishing installation, were closely supervised. The complex investment process, as well as the number of variables, time constraint and the need to perform construction and restoration works at the same time, all contributed to the accumulation of problems. During execution works, the installers faced unforeseen difficulties concerning the structural system and the bearings of floor joists, stair joists, lintels and vaults. When the construction works were ongoing, a competition for the arrangement of the exhibition was resolved and another difficult stage of reaching compromises began. The exhibition project was developed by a team from the Warsaw-based Pl-Studio. The original locations of final installation devices were changed,

Fig. 11. The Museum of Warsaw, the room with a polychrome ceiling in the Szlichtyng tenement house (photo by Marcin Czechowicz, 2018, property of the Museum of Warsaw)

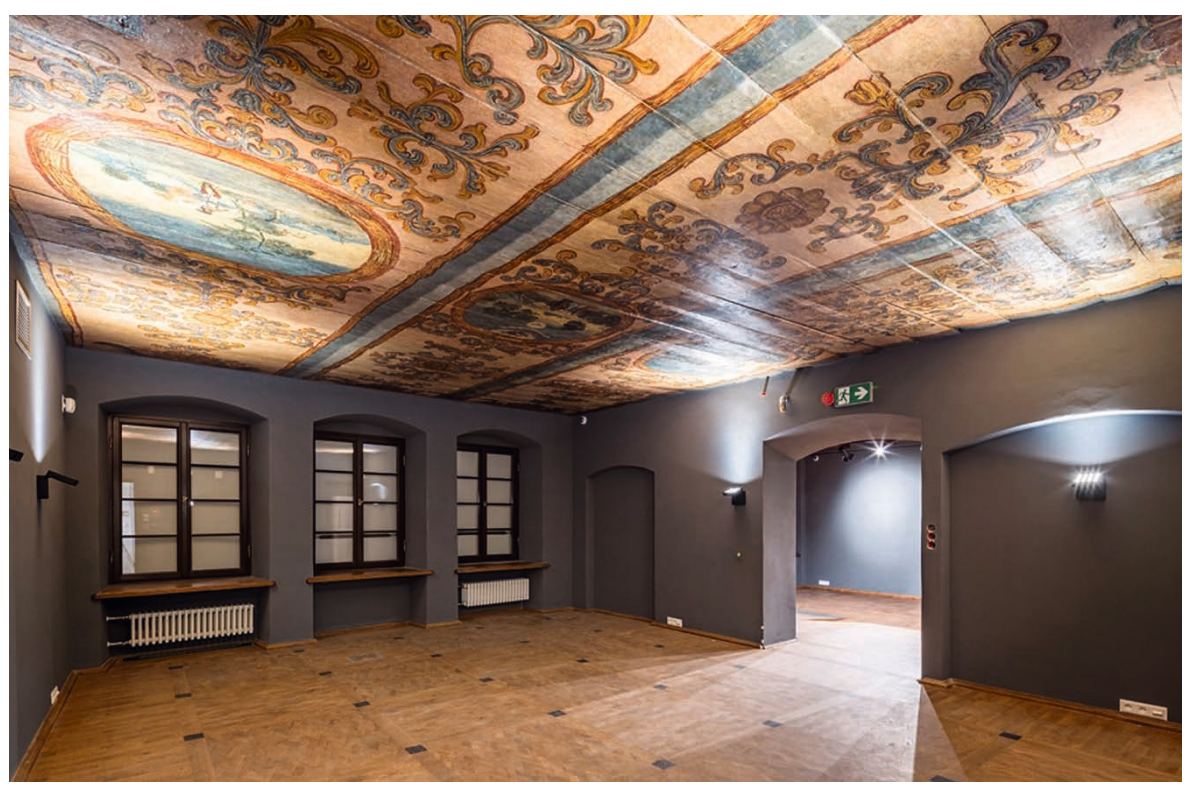


including lightning, fire detectors, warning system speakers, surveillance cameras and even access control. As a result, decisions as to how power cables and optical fibre cables should be distributed were taken on the construction site. A significant change in terms of décor was introduced by transferring frescos dating back to the 1950s and 1960s from the graphic artists' room in the Iskra publishing house at 11 Smolna Street which were at risk of destruction. They were placed on a dedicated substructure by one of the walls within the library. It is the second wall polychrome transfer in the Museum of Warsaw (Dudelewicz, Uchański, 2016).

Discussions and negotiations concerning the exhibition arrangement details only ended with the dedication of the building. Eventually, the designers defended the project based on the authors' right to decide about the final shape of their work, while the interior elements developed by the exhibition creators acquired a form consistent with their role of being subordinate to the exhibit (Figs. 11-16). As a result, a rich work was achieved that was characterised by several narrative layers, an effect of the combined efforts of conservators, many designers, the exhibition's developers, the construction manager and the contractors, all of whom were willing to collaborate and face the challenges posed by both the investor and the exhibition curators. (The project team composed of: architecture: Ewa Wowczak, Jerzy Wowczak; constructions: Stanistaw Karczmarczyk, Wiestaw

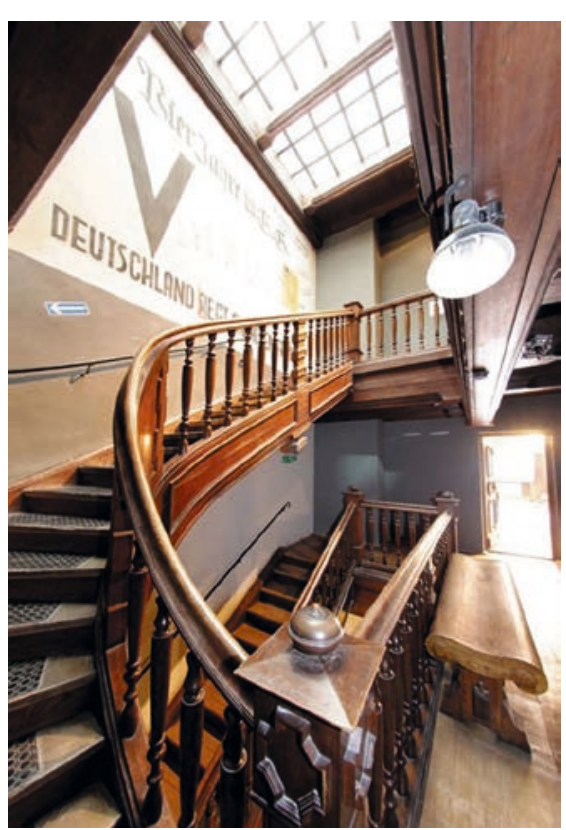
Bereza; sanitary installations: Pawet Budzyński, Marta Ciesielska, Andrzej Ciesielski, electrical installations: Andrzej Nowak, Jacek Balana, construction manager: Robert Wanat).

We hope that when the need for the next reconstruction arises, our successors will treat the artwork that we are handing over with understanding. The final effect can be assessed by analysing the attached pictures. The photographs by Marcin Czechowicz used in the article were made available by the Museum of Warsaw, for which we are truly grateful.

\section{The museum today}

Three years have passed since the objects were put into operation. From the time perspective it can be seen that the formula adopted by the designers and exhibition curators has been successful. The modernist motto "less means more" has acquired a new meaning - "the humbler, the better" - as part of this undertaking. By using the available technical possibilities in a restrained manner, the designers avoided the risk of dominating the existing elements and depreciating their value. Moreover, the reconstruction of the Museum of Warsaw
Fig. 12. Museum of Warsaw, the stairwell in the Baryczka tenement house (photo by Marcin Czechowicz, 2018, property of the Museum of Warsaw)

Fig. 13. Museum of Warsaw, a skylight in the Baryczka tenement house, 2018 (photo by Marcin Czechowicz, 2018, property of the Museum of Warsaw) 
Fig. 14. Museum of Warsaw, the inner yard, 2018 (photo by Marcin Czechowicz, 2018, property of the Museum of Warsaw)

Fig. 15. Museum of Warsaw, office rooms, 2018 (photo by Marcin Czechowicz, 2018, property of the Museum of Warsaw)
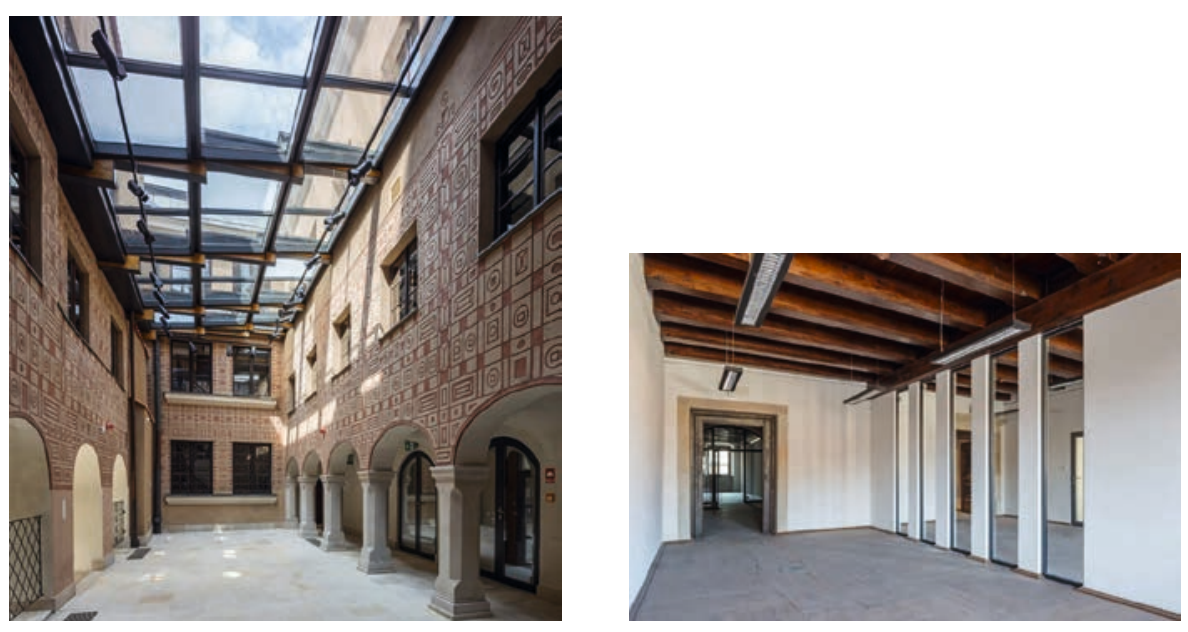

opens room for discussion on sources of inspiration and the limitations of free architectural creation within particular monuments.

Although several modern architectural elements were introduced, the objects did not lose their authenticity. The museum enjoys popularity among the public and integrates Warsaw's residents. It is distinguished by a moderate use of multimedia and the chance of direct contact with historic details offered to visitors. Importantly, the museum's staff all identify with the place, while the restored buildings serve their role of both an exhibition venue and a work space. The restoration won the Architectural Award of the President of Warsaw in the best revitalisation category of 2018, as well as the Accessibility Leader Award 2019 in the historic object category. In 2020, the Museum of Warsaw was awarded as part of the "Zabytek Zadbany" competition organised by the General Conservator of Monuments in the special category: proper use and constant care of a monument. All this proves that the priorities were adequately balanced while taking project-related decisions.

\section{Conclusion}

The tenement houses on Dekert's Side are an example of the continuity of typically Polish conservationist thought. This conclusion made it possible for the designer to put the sign of equality between the value of the historical elements and the compositional value of the space influenced by old

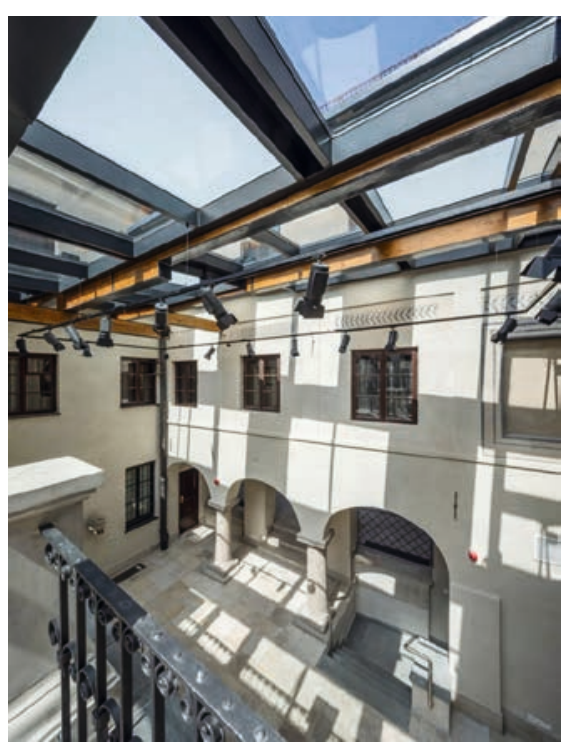
conservationist ideas. The research preceding the design process was performed according to the principle "by interpreting - we understand, by understanding - we appreciate, and by appreciating - we protect" and allowed for the recognition of the complex of tenement houses as a multi-faceted and, at the same time, consistent work of art. The newly added elements are an effect of its reinterpretation. They do justice to the complex's individual characteristics and modern style, respecting its original shape. Being in line with the rules established by previous designers and conservationists, the new elements fit into the overall spatial context. 
Thanks to this, apart from an increase in functionality, an effect of harmonious recomposition has been achieved. The over one-hundred-year-old history of the Museum of Warsaw can be regarded as a permanent conservation completed with the last reconstruction. Therefore, we can develop the aforementioned motto into "by interpreting - we understand, by understanding - we appreciate, by appreciating - we protect, and by protecting - we recompose", leaving room for the interpretation of future generations.

\section{References}

Arszyński, M. (2007). Idea, pamięć, troska. Rola zabytków w przestrzeni spotecznej i formy dziatań na rzecz ich zachowania od starożytności do potowy XX wieku. Malbork: Muzeum Zamkowe.

Bąkowski, K. (1905). O konserwacji zabytków przesztości. Architekt, 3, 33-46.

Beiersdorf, Z. (1998). Konserwacja Krakowa sprzed 100 laty. In J.M. Matecki (Ed.), Kraków przed stu laty (pp. 71-93). Kraków: Muzeum Historyczne Miasta Krakowa: Towarzystwo Mitośników Historii i Zabytków Krakowa.

Bochiński, J. (2013). Od socrealisty do abstrakcjonisty „Kucie kos” Wojciecha Fangora z Muzeum Warszawy. Retrieved from historiaposzukaj,pl/ wiedza,obrazy,878,obraz_kucie_kos.html, (date of access: 2020/01/180).

Ciesielska, D. (2007). Stanistaw Zamecznik. Almanach Muzealny, V, 357-359.

Czaja, R. (Ed.). (2007). Atlas Historyczny Miast Polskich, vol. V. Kraków.

Dąbrowski, K., Żaryn, S. (1955). Polichromowany strop kasetonowy w kamienicy. warszawskiej Rynek Starego Miasta 34. Ochrona Zabytków, 2, 116-124.

Dettloff, P. (2008). Odbudowa i restauracja zabytków architektury w Polsce w latach 1918-1939 teoria i praktyka. Kraków: Universitas.

Dettlof, P. (2010). Dziatalność konserwatorska Towarzystwa Opieki nad Zabytkami Przesztości. In E. Manikowska, P. Jamski (Eds.), Polskie dziedzictwo kulturowe u progu niepodległości wokót Towarzystwa opieki nad Zabytkami Przesztości (pp. 127-158). Warszawa: Ministerstwo Kultury i Dziedzictwa Narodowego. Departament Dziedzictwa Kulturowego: Instytut Sztuki Polskiej Akademii Nauk.

Dudelewicz, J., Uchański, W. (2016). Bezcenne malowidta ścienne na murach Muzeum Warszawy. Retrieved from http//muzeumwarszawy.pl/bezcennemalowidla-scienne-na-murach-muzeum-warszawy/(dateofaccess:2020/01/18).

Dzierwa, K. (2010). Kronika wystaw Towarzystwa Opieki nad Zabytkami Przesztości. In E. Manikowska, P. Jamski (Eds.), Polskie dziedzictwo kulturowe u progu niepodlegtości wokót Towarzystwa opieki nad Zabytkami Przesztości (pp. 283-311). Warszawa: Ministerstwo Kultury i Dziedzictwa Narodowego. Departament Dziedzictwa Kulturowego: Instytut Sztuki Polskiej Akademii Nauk.

Frycz, J. (1973). Neogotyki restauracja zabytków w Polsce. In T. Hrankowska (Ed.), Sztuka 2 połowy XIX wieku, Materiaty Sesji Stowarzyszenia Historyków Sztuki tódź, listopad 1971 (pp. 173-182). Warszawa: PWN.

Frycz, J. (1975). Restauracja i konserwacja zabytków architektury w Polsce w latach 1795-1918. Warszawa: PWN.

Grzelachowski, S. (2010). Autentyzm w kamienicach warszawskiego Rynku Staromiejskiego. Spotkania z Zabytkami, 11-12, 34-41.

Hamnett, C., Shoval, N. (2008). Museums as Flagships of Urban Development. In L. Hoffman, S. Fainstein, D. Judd (Eds.), Cities and Visitors: Regulating people, markets and city space (pp. 219-236). Oxford: Blackwell.

The Charter of Venice. (1964). Retrieved from www.nid.pl/upload/iblock (date of access: 2020/01/18).

Koczorowska, M., Kozarzewski, M., Kutakowska, D., Zalewska, K. Madonna tronująca z dzieciątkiem z kamienicy Rynek Starego Miasta 40. Retrieved from muzeumwarszawy.pl/wp-content/uploads/2019/05/8-madonna.pdf (date of access: 2020/01/18). 
Krawczyk, J. (Ed.). (2012). Wokót Wawelu. Antologia tekstów z lat 1901-1909. Warszawa: Oficyna Wydawnicza „Mówią wieki”.

Krogulec, T. (2007). Inwentarz rysunków architektonicznych kamienic bloku muzealnego w zbiorach Muzeum Historycznego m.st. Warszawy. Almanach Muzealny, V, 123-172.

Królikowski, J.T. (2004). Zaktad Architektury Polskiej i Historii Sztuki. In M. Brykowska (Ed.), Oskara Sosnowskiego świat architektury (pp. 71-74). Warszawa: Oficyna Wydawnicza Politechniki Warszawskiej.

Krzyżanowski, W. (1912). Pamiętnik pierwszego zjazdu mitośników ojczystych zabytków w Krakowie w dniach 3 i 4 lipca 1911 roku, Kraków.

Lalewicz, M., Lisiecki, J. (1932-1933). Wydziat Konserwatorski Towarzystwa Opieki nad Zabytkami Przesztości Okres 1920-1930. Biuletyn Historii Sztuki i Kultury, 1, 45-52.

Manikowska, E. (2010). Od miasta do stolicy. Towarzystwo opieki nad Zabytkami Przeszłości Warszawa. In E. Manikowska, P. Jamski (Eds.), Polskie dziedzictwo kulturowe u progu niepodlegtości wokót Towarzystwa opieki nad Zabytkami Przeszłości (pp. 254-281). Warszawa: Ministerstwo Kultury i Dziedzictwa Narodowego. Departament Dziedzictwa Kulturowego: Instytut Sztuki Polskiej Akademii Nauk.

Muczkowski, J. (1904). Jak konserwować zabytki przeszłości. Architekt, 8-9.

Popiotek, M. (2016). Od kamienicy do muzeum. Warszawa: Muzeum Warszawy.

Ruskin, J. (1849). The seven lamps of architecture. London: Smith, Elder \& Co.

Sas-Zubrzycki, J. (1902). Krótkie myśli z dzieta Ruskina Siedem lamp architektury wraz z uwagami. Lviv.

Sas-Zubrzycki J. (1922). Polish Style - National Style. Lviv.

Sottan, A. (2007). Muzeum Historyczne m. st. Warszawy 1936-2006. Almanach Muzealny, V, 7-54.

Sulimierska, M. (1953). Kowalszczyzna staromiejska XVII i XVIII wieku. Ochrona Zabytków, 2-3, 119-124.

Szmygin, B. (Ed.). (2015). Vademecum konserwatora Zabytków. Warszawa: Polski Komitet Narodowy Międzynarodowej Rady Ochrony Zabytków ICOMOS.

Urbanowicz, B. (1953). Dwie polichromie starego Rynku. Ochrona Zabytków, 2-3, 142-156.

Van Aalst, I., Boogaarts, I. (2003). From Museum to mass entertainment; the evolution of the role of museums in cities. European Urban and Region Studies, 9(3), 195-209.

Wojciechowski, A. (1953a). Polichromia i wnętrza Starego Miasta. Przegląd Artystyczny, 4, 3-15.

Wojciechowski, A. (1953b). O wtaściwą formę wspótpracy plastyków z architektami. Przeglad Artystyczny, 6, 8-11.

Wojciechowski, J. (1934). O kamienicy Baryczków. Architektura i Budownictwo, 3, 90-94.

Wowczak, J. (2019). Wspótczesna restauracja powojennej rekonstrukcji zabytku. Wiadomości Konserwatorskie, 59, 124-131.

Zachwatowicz, J. (1965). O ochronie zabytków w Polsce. Warszawa.

Zachwatowicz, J. (1981). O polskiej szkole odbudowy i konserwacji zabytków. Ochrona Zabytków, 1-2, 4-10.

Zalewska, A. (2013). Program prac konserwatorskich i restauratorskich trzy stropy polichromowane w kamienicy Kleipoldowskiej. Warszawa.

Żaryn, S. (1953a). Stare i nowe portale w kamienicach staromiejskich. Ochrona Zabytków, vol. 2-3, 115-118.

Żaryn, S. (1953b). Zabezpieczenie polichromii w kamienicy rynek St. Miasta 17. Ochrona Zabytków, vol. 2-3, 169-171.

Żaryn, S. (1972). Trzynaście kamienic staromiejskich. Warszawa. 